\title{
Thermal Behavior of Green Roofs Applied to Tropical Climate
}

\author{
Grace Tibério Cardoso ${ }^{1}$ and Francisco Vecchia ${ }^{2}$ \\ ${ }^{1}$ Program in Environmental Engineering Sciences, School of Engineering of São Carlos, University of São Paulo (USP), \\ P.O. Box 292, 13560-970 São Carlos, SP, Brazil \\ ${ }^{2}$ School of Engineering of São Carlos, University of São Paulo (USP), P.O. Box 292, 13560-970 São Carlos, SP, Brazil
}

Correspondence should be addressed to Grace Tibério Cardoso; gracetiberio@hotmail.com

Received 19 November 2012; Accepted 5 December 2012

Academic Editor: Eric Lui

Copyright (C) 2013 G. Tibério Cardoso and F. Vecchia. This is an open access article distributed under the Creative Commons Attribution License, which permits unrestricted use, distribution, and reproduction in any medium, provided the original work is properly cited.

\begin{abstract}
The main goal of this paper is to present results on an experimental field about the green roofs thermal behavior, compared to other traditional roof covering systems. On the one hand, it intends to describe shortly the constructive system of a green roof with a lightweight building system, which has a sustainable building materials character and, on the other, it worries with the water reuse and with the run-off delay. The main methodological procedure adopted to study the thermal behavior of green roof was installing thermocouples to collect surface temperatures and indoor air, later comparing them with existing prototypes in an experimental plot. The thermal behavior analysis of cover systems was assessed by a representative episode of the climate fact, based on the dynamic climate approach. The experimental results from internal air temperature measurements show that the green roofs applied to warm and dry climates also provide an interesting time lag with surface and internal air temperature reduction.
\end{abstract}

\section{Introduction}

Across the country, the urbanization process has been problematic for the occurrence of several damages, for example, floods observed during the spring and summer, due to the concentration trend of consecutive rainy days. Green roofs have the potential to retain stormwater on the roof surface reducing the runoff effect by retaining part of the rainfall and distributing the runoff over a long-time period [1], consequently reducing the pollution of urban rainwater from runoff by absorbing and filtering pollutants [2] and lowering the thermal loading on buildings [3]. Other factors may be added to this issue as the increase of air temperature, at micro- and mesoclimatic scales; the increasingly visible role of urban heat islands and water shortages in big cities, so green roofs can help buildings to keep cool in summer; and also the reduction building's energy consumption by direct shading, evaporative cooling, and additional insulation $[4,5]$.

The technology underlying green roof design is complex, but given the intrinsic benefits of green roofs, there has been a desire by architects to adopt this new technology. In city centres, where access to green space is negligible, green roofs create space where people can rest and interact with friends or business colleagues [3]. Green roofs provide a psychological benefit because of their appearance, which differs greatly from ordinary roofs. Therefore, aesthetic value is the most apparent benefit of vegetated roofs [6].

Consequently, green roofs are increasingly being incorporated as a sustainable practice in building design, often without specific attention to designing the roof to achieve specific functions, or to the conditions of a specific climatic region [7].

Concern about environmental and sustainability issues in society as a whole has led to the development of building technologies that aimed at less environmental impact. In this context, an extensive research about green roofs has been developed for at least eight years at the School of Engineering of São Carlos, University of São Paulo, USP, which involves three distinct areas of scientific knowledge: (1) thermal behavior, (2) building systems, and (3) reuse and delay of storm water runoff through green roofs.

This paper explores the analysis of the thermal performance of roofs, evaluating a green roof and compared to traditional roof systems. It describes briefly the green roof construction: the establishment of support systems, drainage and waterproofing of surfaces, and placement of grass, along 


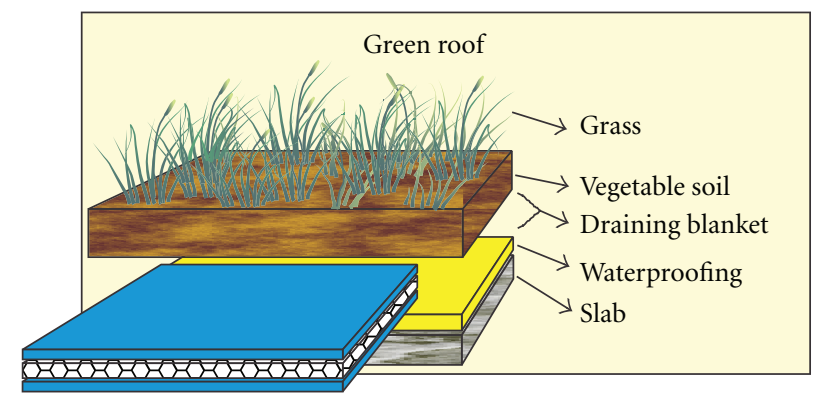

FIGURE 1: Layers of the green roof.

with the climate analysis used to compare the thermal performance of all roof systems. Finally, it shows the results of the surface temperatures of the systems analyzed by comparing them with the values of the external air temperature.

\section{Material and Method}

2.1. Building Method. The green roofs project aims to use materials and methods that cause the least environmental impact at all stages of construction and throughout the lifetime of the building. For its evaluation, an experimental green roof installation using renewable materials such as polyurethane resin waterproofing derived from castor oil (Ricinus communis) was performed. This resin was developed by the Group of Analytical Chemistry and Polymer Technology, Chemistry Institute of São Carlos, University of São Paulo, and is marketed by Cequil - Central Ind. Des. Polímeros Ltda., company located in the city of Araraquara, São Paulo, Brazil.

In addition to the sustainable construction aspects, the application of green roofs aims to contribute to the energy efficiency of buildings reducing artificial conditioning and meeting the requirements of the environmental comfort minimizing the values of the internal air temperature and surface temperature of the roof system. These two aspects also contribute to reducing health problems (respiratory) and to increase productivity through the promotion of appropriate work conditions (schools, factories and offices, and hospitals and clinics), especially for buildings which seek to reduce their operating costs.

The green roof is formed by the substrate (grass with vegetable soil), a draining blanket and a waterproofing layer. This set should be placed on a support structure (Figure 1).

2.2. Lightweight Building System. The building system is very simple, but requires care, regarding the choice of the substrate, the drainage system, and in particular of the waterproofing.

The green roof was designed to have the lowest overhead possible weight over the pillars and building foundation, using building techniques that could reduce the weight of its components. Preliminary studies indicate equivalence between the weight of the green roof and the weight of a traditional roof system of ceramic tiles.

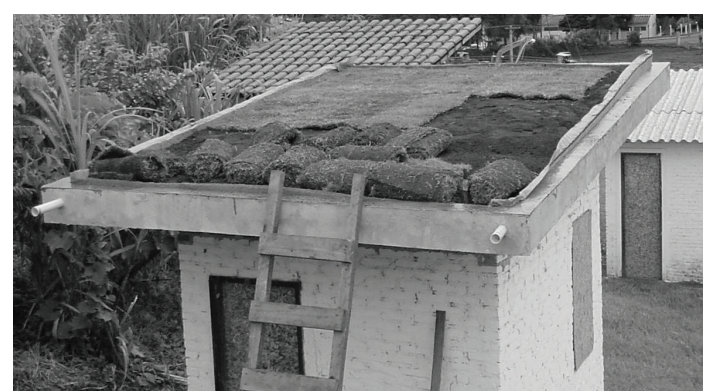

FIGURE 2: Green roof: applying of emerald grass (Paspalum notatum).

2.3. Description of the Practical Steps of Implementing a Green Roof System Weight. For the experiment, it was constructed a premolded slab, composed by ceramic tile and prefabricated concrete joist, applying $30 \mathrm{~mm}$ of concrete over this set. Above this slab, a ledge was constructed with two rows of massive bricks with $0.10 \mathrm{~m}$ wide, to control the substrate, preventing it to run away from the side of the roof. After the water infiltration and the passing through the substrate and the drainage material, the effluent must leave filtrated to the PVC collection tube that was installed in the ledges, to remove the accumulated water.

2.4. Waterproofing. After construction of the ledge, a cement was applied on the surface of the premolded slab to increase the adhesion of the waterproofing resin and, after drying, waterproofing was applied with due care to prevent the water infiltration and other potentially aggressive agents that may attack the reinforcement of concrete causing its corrosion, or to cross the slab causing leaks and consequent formation of mold and fungus.

The waterproofing with polyurethane resin derived from vegetable oil contributes to a sustainable building and causes no harm to the environment or health, because it comes from a renewable resource and it is not toxic [8]. This resin has peculiar importance due to its applicability in engineering that represents a promising research field of new building materials.

2.5. Drainage. The drainage element MacDrain 2L (partnership with Maccaferri do Brasil Ltda.) is a light and flexible geosynthetic drain whose core is formed by a threedimensional blanket composed by filaments of polypropylene with thickness between 10 and $18 \mathrm{~mm}$. This set is welded between one or two geotextiles.

2.6. The Grass. In the green roof emerald grass (Paspalum notatum) was used, because it is resistant to the action of sunlight and trampling (Figure 2).

\section{Climate Analysis and Thermal Behavior of Green Roof}

3.1. Climate Analysis. The climate approach used in the research that defined the experimental day is based on 
dynamic climatology, once incorporated into the experimental study, the dominant atmospheric state during the analysis period. Moreover, the study used as a reference the Climatological Normals 1961-1990 [9].

According to Köppen's classical classification [10], the climate of São Carlos' region is Cwa, in other words, wet summer and dry winter. São Carlos is located at $22^{\circ} 01$ South latitude and $47^{\circ} 53^{\prime}$ West longitude and its altitude is about 890 meters. From the perspective of the dynamic climate approach, São Carlos is characterized as a region with passages of cold fronts throughout the year. According to Monteiro [11], the passage of these air masses can be divided into two main stages called prefrontal and postfrontal. The prefrontal phase is divided into two stages, foreshadowing and advancement, and the postfrontal phase is divided into domain and transition phases.

Therefore, it is an approach in which the genetic study of the climate incorporates the mechanisms of the atmospheric circulation, which is acting in the local area and in the built space, through the action of cold fronts (Atlantic Polar) and because of the circulation of the masses of air (Tropical and Atlantic Polar) that, in last analysis, answer for the climatic rhythms. Through those rhythms, expressed by the climatic elements, it is possible to settle down episodes characterized and representative, through sequences of the Weather, that represent more appropriately the climatic fact. According to Cardoso et al. [12], "the episodes should be characterized by their repercussion on the built space and, in particular, on the building envelope, defining their thermal and energy evaluation."

Considering the atmospheric systems that act in the local area, it is possible to determine the analysis period in function of the problem requested by the study object. To correlate the predominant atmospheric system, during the chosen event, the meteorological data must be taken in surface and in intervals of at least 1 hour to accompany the progress of a polar front, above the local area in analysis, from the prefrontal stage (during the "announcement" and "progress" phase until the dissipation, in the postfrontal stage, in the "domain" and "transition" phases, when the Polar air mass is in tropical phase).

In this paper, the period of foreshadowing and advancement of Atlantic Polar mass was chosen, since in these situations there is an overheating in the area penetrated by the front, raising the values of outside air temperature and also experiencing a consequent decrease of the relative humidity's values. Other changes can be seen in the climatic elements like alterations in prevailing winds' system, interruption of the sinusoid curve of barometric pressure, and changes in cloudiness and cloud formation, among others.

From this understanding based on dynamic climatology, it is possible to obtain the definition of representative episodes, according to Vecchia [13], in which the properties of air masses that act on a certain place are considered. Thus, it means to understand how the climate works, based on the understanding of the general and regional atmospheric circulation, approaching to the definition of weather adopted by the World Meteorological Organization and cited by

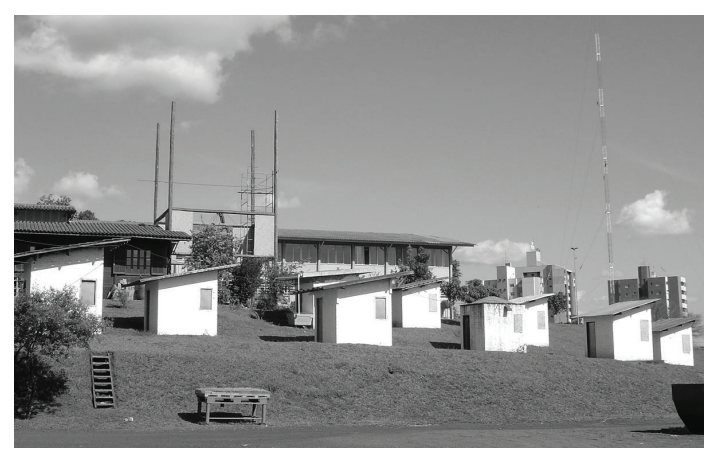

FIGURE 3: View of the north façade of the experimental plot which has 10 prototypes monitored by automatic data records, built in real scale, at the School of Engineering of São Carlos, USP.

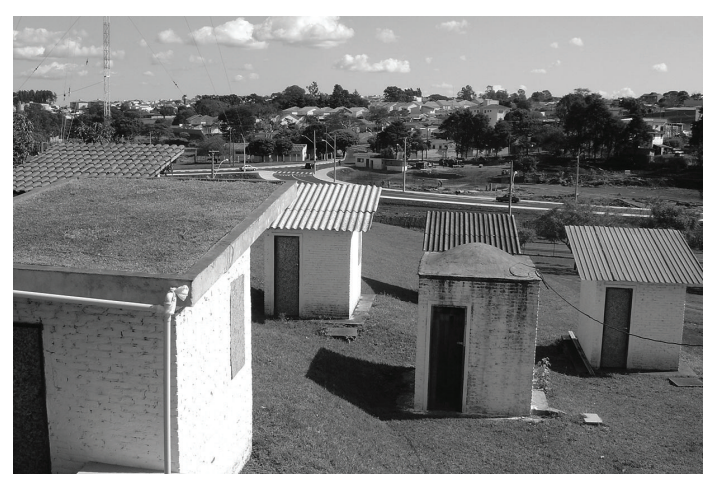

FIGURE 4: Overview of the prototypes with different roof systems.

Allard and Santamouris [14]: "the totality of meteorological elements, in their habitual succession and in a certain period, characterizes the atmosphere's state."

\section{Green Roof: Thermal Behavior Analysis}

4.1. Methodology. The methodological procedures for studying the thermal behavior of different roof systems included the use of two automated systems for the acquisition of the main meteorological data and the records necessary for the thermal performance of roof systems, at existing prototypes in real scale $(2.30 \mathrm{~m} \times 2.70 \mathrm{~m} \times 2.60 \mathrm{~m})$ built at the School of Engineering of São Carlos, University of São Paulo (Figure 3).

All prototypes have a concrete floor (raft flooring $0.15 \mathrm{~m}$ thick), walls of massive ceramic bricks $(0.20 \mathrm{~m} \times 0.10 \mathrm{~m} \times$ $0.05 \mathrm{~m}$ ) painted white, a wooden door, and window at, respectively, south and north facades (Figure 4). The only variations implemented refer to different types of roof systems. Doors and windows were kept closed during the experiment to obtain more precise values of the temperatures, without the influence of natural ventilation [15].

It was compared with the most commonly roof systems used in Brazil, which are the coverings of ceramic tiles, and cement tiles, galvanized steel tiles, along with other systems common in Latin America, which is the slab without ceramic tiles. In this case, a slab was built with premolded concrete 
beams with ceramic sealing, waterproofed with polyurethane resin based on castor oil (Ricinus communis). These roofs were used for comparison of thermal behavior among themselves and with green roof proposed.

4.2. Automatic Measurement and Thermocouples Type T. Each prototype has T-type thermocouples (copper constantin) for reading the surface temperature and internal air temperature. The traditional globe temperature measurements were replaced by readings of surface temperatures, considered more appropriate to study that. In turn, it does not intend to compare these data with other experiments at other locations.

The measurements are designed to study the thermal behavior of surfaces and indoor air, comparing them later with existing prototypes in experimental plot, at the School of Engineering of São Carlos. For this, thermocouples were arranged on the inner surfaces, three for each building element, installed at the closest point from the geometric center of the prototype, taking the average of them to represent the values of the surface temperatures. Another thermocouple was installed approximately 1 meter from the floor, to perform measurements of internal air temperatures in the inhabited area. There are also thermocouples placed at $2.10 \mathrm{~m}$ and $0.10 \mathrm{~m}$ from the floor to check the internal air temperature gradients, following regulatory and other purposes that were not considered in this study. Therefore, the values for the internal air temperature at each prototype only refer to the readings obtained at 1 meter height from the floor.

These data were recorded in a datalogger CR10X, from Campbell Scientific Inc., coupled to a multiplexer AM 416, 32-channel, with battery system and solar panel installed in one of the prototypes at experimental plot.

\section{Results}

5.1. Thermal Behavior and Thermal Performance of Green Roof. October 9, 2004 was taken as the reference day from the representative episode of October 4 to October 10, 2004, for the study of thermal behavior and thermal performance of green roof due to its remarkable characteristic of heat, surpassing the value of $24.7^{\circ} \mathrm{C}$, which is the average of maximum obtained of climatological normals to São Carlos from 1961 to 1990 . The value recorded in this representative episode was just below the absolute maximum temperature recorded on October 12, $1963\left(36.4^{\circ} \mathrm{C}\right)$, which against the maximum temperature of the climate episode adopted $\left(34^{\circ} \mathrm{C}\right)$ means a difference of approximately $2.5^{\circ} \mathrm{C}$. Therefore, October 9 can be considered remarkable for its value. The temperature range recorded on this day was $21.7^{\circ} \mathrm{C}$, with a minimum temperature of $12.7^{\circ} \mathrm{C}$ and a maximum of $34^{\circ} \mathrm{C}$. This day was cloudless, with values of solar radiation reaching $900 \mathrm{~W} / \mathrm{m}^{2}$.

5.2. Thermal Behavior. The thermal behavior of green roof can be observed in Figure 5, where the maximum outside temperature reaches about $34^{\circ} \mathrm{C}$, occurring in the afternoon

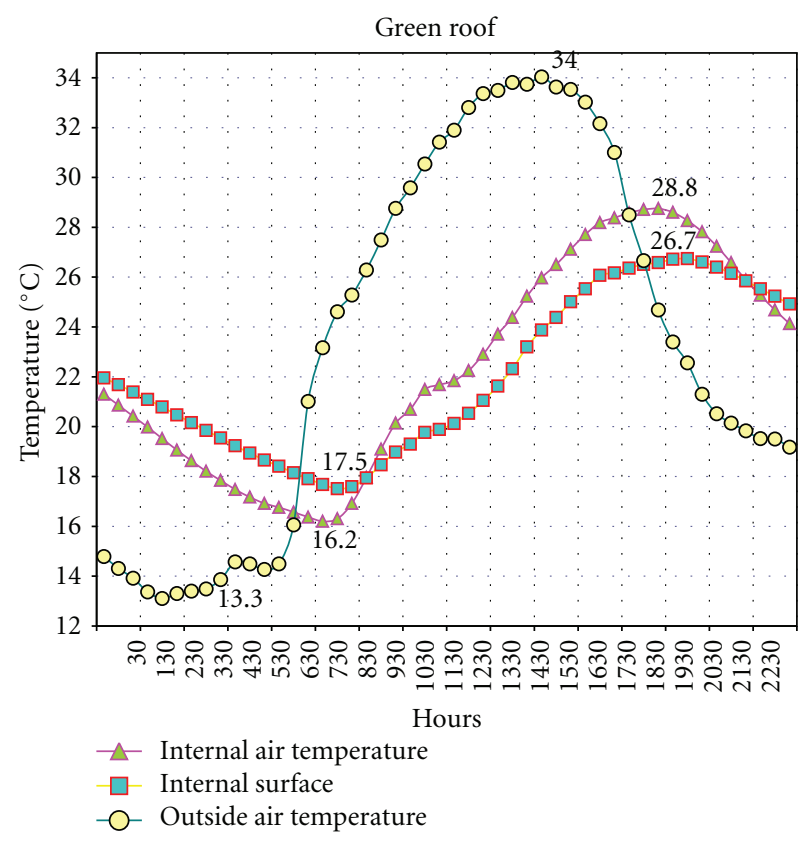

Figure 5: Green roof chart to October 9th, 2004.

(registered at 2:30 pm on October 9, 2004), on Atlantic Tropical mass' domain and hot and dry characteristic (habitual on São Carlos' region in spring-summer transition).

The internal air temperature at this same time was $26^{\circ} \mathrm{C}$, a difference of $8^{\circ} \mathrm{C}$ in relation to $34^{\circ} \mathrm{C}$ from maximum outside temperature. It was recorded $24^{\circ} \mathrm{C}$ on the internal surface of the slab that supports the green roof, that is, a difference of $10^{\circ} \mathrm{C}$ in relation to the outside air temperature. The heat exchange process is slowed by the action of the green roof insulation, due to its thermal physics constitution, the mass and thermal resistance, and shading action caused by the grass, among other beneficial thermal effects characteristic of this type of roof system.

Figure 5 shows that there is a thermal lag (time that external heat takes to penetrate in internal environment) of approximately 4 hours, followed by a thermal damping (maintaining the internal temperature less than outside air temperature) about $8^{\circ} \mathrm{C}$. The temperature range of internal air temperature is about $12.5^{\circ} \mathrm{C}$, while the temperature range of internal surface temperature of the green roof is $10^{\circ} \mathrm{C}$. It means that the internal surface of the green roof is absorbing heat at the time of the peak absorption; thus, it tends to minimize the values of internal air temperature. At the peak of air temperature, it is verified that the difference between the outside air temperature and the internal air temperature is $5.3^{\circ} \mathrm{C}$. However, the maximum temperature of the outside air occurs at 2:30 pm, while the indoor air is maximum at $6 \mathrm{pm}$, that is, with a thermal lag of 3 hours and 30 minutes.

5.3. Thermal Performance. The thermal performance study was to analyze the different temperatures of a green roof, at different points, and compare them with the temperatures of four other types of roof systems (Figure 6): (1) galvanized steel tiles, (2) cement tiles, (3) premolded ceramic slab 
TABLE 1: Comparison between thermal ranges and values of internal surface temperatures (tsi) of the different systems analyzed-October 9, 2004.

\begin{tabular}{|c|c|c|c|c|c|c|}
\hline & $\begin{array}{c}\text { tsi }\left({ }^{\circ} \mathrm{C}\right) \text { ceramic } \\
\text { tiles } \\
\end{array}$ & $\begin{array}{c}\text { tsi }\left({ }^{\circ} \mathrm{C}\right) \text { galvanized } \\
\text { steel tiles }\end{array}$ & $\begin{array}{c}\text { tsi }\left({ }^{\circ} \mathrm{C}\right) \text { cement } \\
\text { tiles }\end{array}$ & $\begin{array}{l}\text { tsi }\left({ }^{\circ} \mathrm{C}\right) \text { ceramic } \\
\text { slab }\end{array}$ & $\begin{array}{l}\text { tsi }\left({ }^{\circ} \mathrm{C}\right) \text { green } \\
\text { roof }\end{array}$ & $\begin{array}{c}\text { Outside air } \\
\text { temperature }\left({ }^{\circ} \mathrm{C}\right)\end{array}$ \\
\hline Maximum & 50.9 & 57.8 & 48.6 & 45.0 & 26.7 & 34.0 \\
\hline Average & 32.9 & 35.9 & 25.6 & 31.8 & 22.1 & 27.2 \\
\hline Minimum & 8.5 & 9.5 & 9.5 & 11.5 & 17.5 & 12.7 \\
\hline Thermal range & 42.5 & 48.4 & 39.1 & 33.4 & 9.2 & 21.4 \\
\hline
\end{tabular}

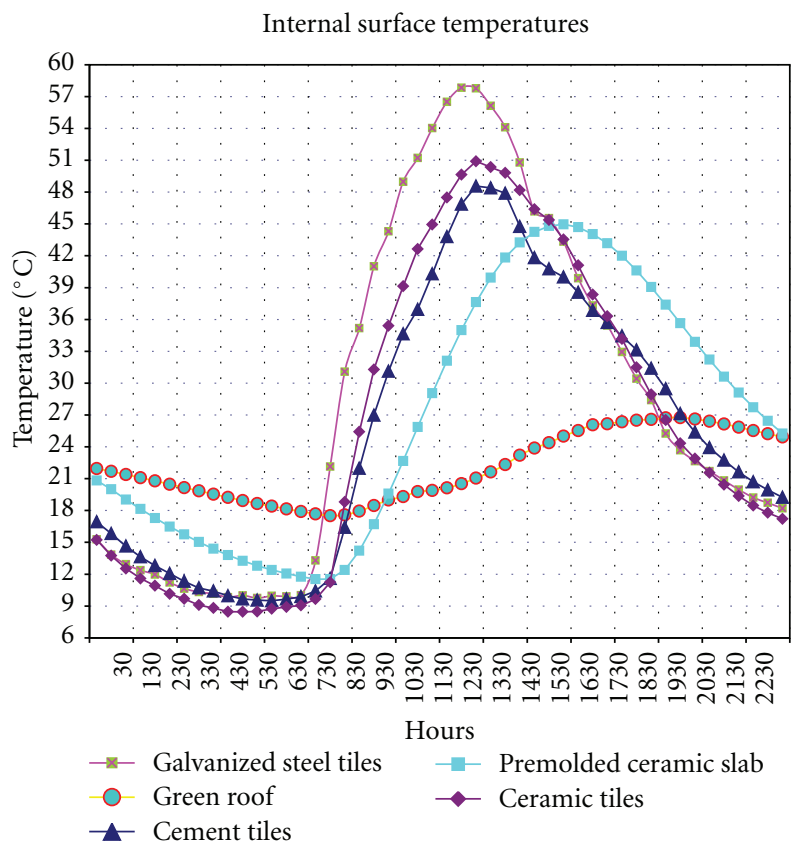

FIGURE 6: Internal surface temperatures chart.

without tiles and waterproofing resin derived from vegetable oil (painted white), and (4) ceramic tiles.

Two main aspects are noted in the chart (Figure 6) in relation to the thermal performance of the green roof. First, the thermal lag observed between green roof and the traditional roof systems is more than seven hours. It means that the heat starts to penetrate the green roof during the night (when the outside temperatures tend to be smaller than the interior ones) about 8:00 pm.

The second aspect is that the thermal damping registered, related to the hourly values of internal surface temperature in green roof, is higher than $20^{\circ} \mathrm{C}$, as compared with other roof systems. The range of thermal variation in green roof (lower temperature compared to higher that occurs inside the green roof prototype) is $6^{\circ} \mathrm{C}$. It was recorded in this remarkable day of heat: minimum temperature (at dawn) was $18^{\circ} \mathrm{C}$ and maximum temperature was $27^{\circ} \mathrm{C}$ (about 8:30 pm).

Therefore, when the green roof is compared to other roof systems, it is presented as the best thermal performance, since it has the lowest temperature range $\left(60^{\circ} \mathrm{C}\right)$. Furthermore, the surface temperatures contribute in providing thermal energy during the night (it remains higher than the values recorded for the internal air temperature) and, on the other hand, it absorbs heat in the afternoon, when it is maintained at temperatures below the indoor air.

Traditional covers in Brazil tend to react almost immediately to the values of outside air temperature and especially in relation to the action of solar radiation incident on the toppings. A concrete covering slab on upper surface sealed with white natural resins, also reacts to the external climate, but with a delay of about three hours, due to its thermal physics formation of significant thermal mass. It should be noted that this type of cover system (slab without tiles) is not widely used in Brazil; however, similar coverages are quite common in South America, Mexico, Caribbean, and Central America.

\section{Discussion}

The main points arising from the experimental evaluation of this green roof system referred to in this paper, are the following. First, after the empirical verification of the green roof weight, it is concluded that it can be applied in large scale. The load tests performed show that the self-weight of green roof may vary between $96.4 \mathrm{~kg} / \mathrm{m}^{2}$ (substrate without water) and $285.4 \mathrm{~kg} / \mathrm{m}^{2}$ (saturated with water). This allows concluding that the maximum load exerted per square meter of a green roof (saturated with water) is equivalent to the load exerted by a set of traditional ceramic roof, considered the wooden structure and the self-weight of the tiles. Thus, it is possible to say that regarding self-weight, the green roof is suitable to buildings.

The second aspect is about the thermal behavior and thermal performance of green roof. As for the thermal aspect, it is important checking its temperature range and compare it to other roof systems that were listed for the verification and comparison among them. Thus, thermal ranges recorded are expressed in Table 1.

Table 1 refers to internal surface temperatures recorded in each prototype. It shows that the lower temperature range belongs to green roof $\left(9.2^{\circ} \mathrm{C}\right)$. This roof system presents greatest difficulty in exchanging heat with the outside environment. But the galvanized steel tiles (without thermal insulation) has the highest thermal range $\left(48.4^{\circ} \mathrm{C}\right)$, implying a greater and faster process of heat exchange between externalinternal environments.

It should be noted that the effect of surface temperatures affects not only the increase in internal air temperature, but also causes discomfort (heat exchange by radiation that is 
TABLE 2: Comparison between thermal ranges and values of internal air temperatures (tbs) of the different systems analyzed-October 9, 2004.

\begin{tabular}{|c|c|c|c|c|c|c|}
\hline & $\begin{array}{c}\text { tbs }\left({ }^{\circ} \mathrm{C}\right) \text { ceramic } \\
\text { tiles }\end{array}$ & $\begin{array}{c}\text { tbs }\left({ }^{\circ} \mathrm{C}\right) \text { galvanized } \\
\text { steel tiles }\end{array}$ & $\begin{array}{c}\text { tbs }\left({ }^{\circ} \mathrm{C}\right) \text { cement } \\
\text { tiles }\end{array}$ & $\begin{array}{c}\text { tbs }\left({ }^{\circ} \mathrm{C}\right) \text { ceramic } \\
\text { slab }\end{array}$ & $\begin{array}{c}\text { tbs }\left({ }^{\circ} \mathrm{C}\right) \text { green } \\
\text { roof }\end{array}$ & $\begin{array}{c}\text { Outside air } \\
\text { temperature }\left({ }^{\circ} \mathrm{C}\right)\end{array}$ \\
\hline Maximum & 30.4 & 45.0 & 31.0 & 34.7 & 28.8 & 34.0 \\
\hline Average & 24.1 & 26.5 & 24.5 & 27.1 & 22.4 & 27.2 \\
\hline Minimum & 15.2 & 11.5 & 14.4 & 14.8 & 16.2 & 12.7 \\
\hline Thermal range & 15.2 & 33.4 & 16.5 & 19.9 & 12.6 & 21.4 \\
\hline
\end{tabular}

independent of the physical environment). It depends on the relationship between the proportion of radiating surfaces and individuals' surfaces exposed, and it is called form factor.

Note also that, on average, the skin's temperature is normally between 31 and $34^{\circ} \mathrm{C}$ [16], which means that from these values the human body is gaining heat radiation. Therefore, the surfaces of roof systems that have values above this temperature range will emit radiant energy to all occupants of interior environments.

The graph of the interior surface temperatures (Figure 6) shows that a galvanized steel roof system supplies heat from $8 \mathrm{am}$ to $6 \mathrm{pm}$, when it reaches and maintains the values of its temperatures higher than $33^{\circ} \mathrm{C}$, on a clear day, with solar radiation incidence between 900 and $1000 \mathrm{~W} / \mathrm{m}^{2}$, as shown in the graph (Figure 6).

In turn, cement tiles system exceeded $33^{\circ} \mathrm{C}$ from $10 \mathrm{am}$ to $6: 30 \mathrm{pm}$ under identical conditions to the galvanized steel roof system. The ceramic tile reaches $33^{\circ} \mathrm{C}$ at 9:30 am until $6: 30 \mathrm{pm}$ So, it exhibits similar behavior to cement tiles roof system.

A traditional roof system in Brazil, premolded ceramic slab with applied concrete layer of approximately $250 \mathrm{~mm}$, waterproofed by white vegetable resin, thus without any type of tile, reaches $33^{\circ} \mathrm{C}$ at $12 \mathrm{am}$ until $8: 30 \mathrm{pm}$ due to its thermophysical constitution, such as its thermal mass and absorptance.

Unlike all other roof systems, green roof does not reach $33^{\circ} \mathrm{C}$ under the same conditions, since its maximum internal surface temperature was verified experimentally $\left(26.7^{\circ} \mathrm{C}\right)$, being below the maximum internal air temperature $\left(28.8^{\circ} \mathrm{C}\right)$. This fact means that the green roof internal surfaces contributed to the absorption of the internal heat which occurs during the critical period in the afternoon.

Internal air temperature also expresses the perception of thermal comfort and allows estimating the thermal behavior and thermal performance of indoor environments. In Table 2, it can be verified that the most appropriate performance also belongs to green roof, which showed values around $28.9^{\circ} \mathrm{C}$ for its maximum temperature.

Comparing this value with maximum outside temperature $\left(34^{\circ} \mathrm{C}\right)$, a $5^{\circ} \mathrm{C}$ difference is obtained indicating the possibility of maintaining internal temperature below the exterior, without the application of passive systems, or even air conditioners.

It is also noted that the maximum value found for the air temperature inside the green roof system remained below $29-32^{\circ} \mathrm{C}$, but not at the peak of outside temperature $\left(34^{\circ} \mathrm{C}\right.$ at
2:30 pm but $28.8^{\circ} \mathrm{C}$ at $7 \mathrm{pm}$ ). It is a delay of approximately 5 hours.

At the same time, the comparison is expressed as follows: external temperature $34^{\circ} \mathrm{C}$ against $26^{\circ} \mathrm{C}$ internal temperature of the green roof, that is, a thermal damping of $8^{\circ} \mathrm{C}$. This situation is acceptable for the thermal behavior on this day (October 9, 2004) of exceptional warmth, which presented with average values above the maximum for this episode of climate in the region of São Carlos, SP, Brazil.

\section{Conclusions}

The load tests have shown that the self-weight of a green roof can vary from $96.4 \mathrm{~kg} / \mathrm{m}^{2}$ with dry substrate to around $285.4 \mathrm{~kg} / \mathrm{m}^{2}$ with saturated substrate. From these results it can be concluded that the maximum load that the green roof substrate (saturated) exerts per square meter is equivalent to the load exerted by the set of a covering of ceramic tiles. After this empirical verification, it is possible to say that the green roof is really light and can be applied on a large scale.

As for the thermal aspect, it was verified that the green roof had the lowest temperature range, compared to other roofing systems used in this paper. Thus, it is possible to say the green roof has greater difficulty to perform heat exchange between interior and exterior environments.

The results showed that the green roof has the most suitable performance, since the maximum value for the internal air temperature was below the maximum outside air temperature.

\section{Acknowledgments}

The authors are grateful to CNPq, FAPESP. They gratefully acknowledged companies that provided materials and products essential to the accomplishment of this paper: Campbell Scientific of Brazil, Maccaferri do Brasil Ltda., and Cequil Central Ind. Des. Polímeros Ltda., and the laboratory building staff for their technical assistance in the experiments.

\section{References}

[1] A. Teemusk and Ü. Mander, "Rainwater runoff quantity and quality performance from a greenroof: the effects of short-term events," Ecological Engineering, vol. 30, no. 3, pp. 271-277, 2007.

[2] A. Moran, B. Hunt, and G. Jennings, "North Carolina field study to evaluate greenroof runoff quantity, runoff quality, and plant growth," in Proceedings of the ASAE Annual International 
Meeting, pp. 1-15, Las Vegas, Nev, USA, July 2003, Paper No. 32303.

[3] A. Teemusk and Ü. Mander, "Greenroof potential to reduce temperature fluctuations of a roof membrane: a case study from Estonia," Building and Environment, vol. 44, no. 3, pp. 643-650, 2009.

[4] M. Santamouris, C. Pavloua, P. Doukasa et al., "Investigating and analysing the energy and environmental performance of an experimental green roof system installed in a nursery school building in Athens, Greece," Energy, vol. 32, no. 9, pp. 17811788, 2007.

[5] H. Takebayashi and M. Moriyama, "Surface heat budget on green roof and high reflection roof for mitigation of urban heat island," Building and Environment, vol. 42, no. 8, pp. 2971-2979, 2007.

[6] Green Roofs for Healthy Cities. ZinCo Canada Inc., http:// greenroofs.org/, 2006.

[7] M. T. Simmons, B. Gardiner, S. Windhager, and J. Tinsley, "Green roofs are not created equal: the hydrologic and thermal performance of six different extensive green roofs and reflective and non-reflective roofs in a sub-tropical climate," Urban Ecosystems, vol. 11, no. 4, pp. 339-348, 2008.

[8] J. M. Cangemi, A. M. Santos, and S. C. Neto, "A Revolução Verde da Mamona," Química Nova na Escola, vol. 32, no. 1, pp. 3-8, 2010.

[9] Brasil, Ministério da Agricultura e Reforma Agrária. Normais Climatológicas (1961-1990), Departamento Nacional de Meteorologia, Brasilia, Brazil, 1992.

[10] World Meteorological Organization, http://www.wmo.int/ pages/themes/climate/statistical_depictions_of_climate.php, 2005.

[11] C. A. F. Monteiro, A Dinâmica Climática e as Chuvas do Estado de São Paulo: Estudo Geográfico sob Forma de Atlas, Universidade de São Paulo, Instituto de Geografia, São Paulo, Brazil, 1967.

[12] G. T. Cardoso, S. C. Neto, and F. Vecchia, "Rigid foam polyurethane (PU) derived from castor oil (Ricinus communis) for thermal insulation in roof systems," Frontiers of Architectural Research, vol. 1, no. 4, pp. 348-356, 2012.

[13] F. Vecchia, Clima e ambiente construído: a abordagem dinâmica aplicada ao Conforto Humano [thesis], Universidade de São Paulo, 1997.

[14] F. Allard and M. Santamouris, Natural Ventilation in Buildings, James \& James, London, UK, 1998.

[15] G. Cardoso, Characterization of Rigid Polyurethane Foam (PU) Extracted From: Castor Oil (Ricinus Communis) For Building Insulation, VDM Verlag Dr. Müller, Saarbrücken, Germany, 2011.

[16] M. Docherty and S. V. Szokolay, Climate Analysis. Brisbane, PLEA: Passive and Low Energy Architecture International, University of Queensland Printery, 1999. 

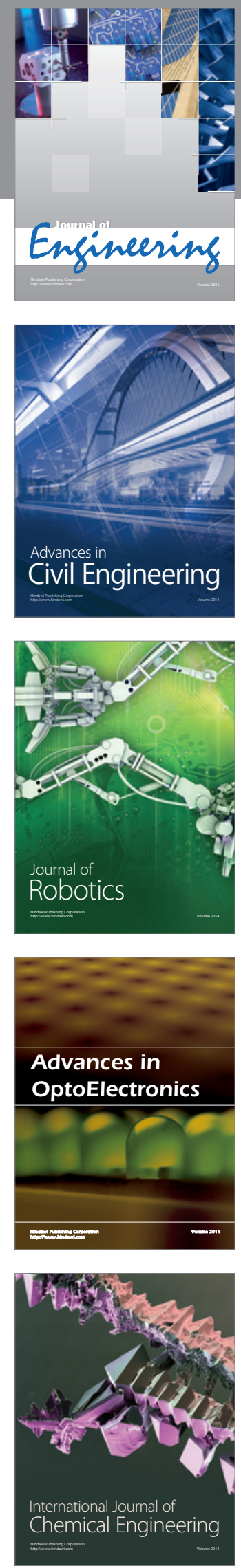

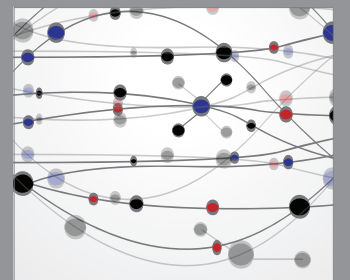

The Scientific World Journal
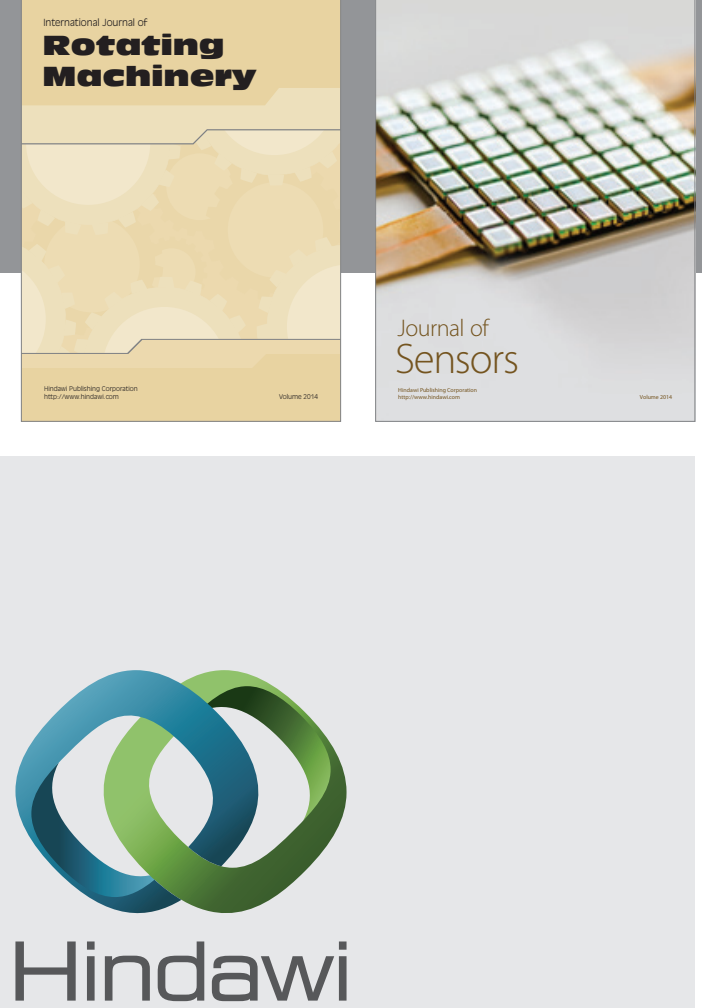

Submit your manuscripts at http://www.hindawi.com
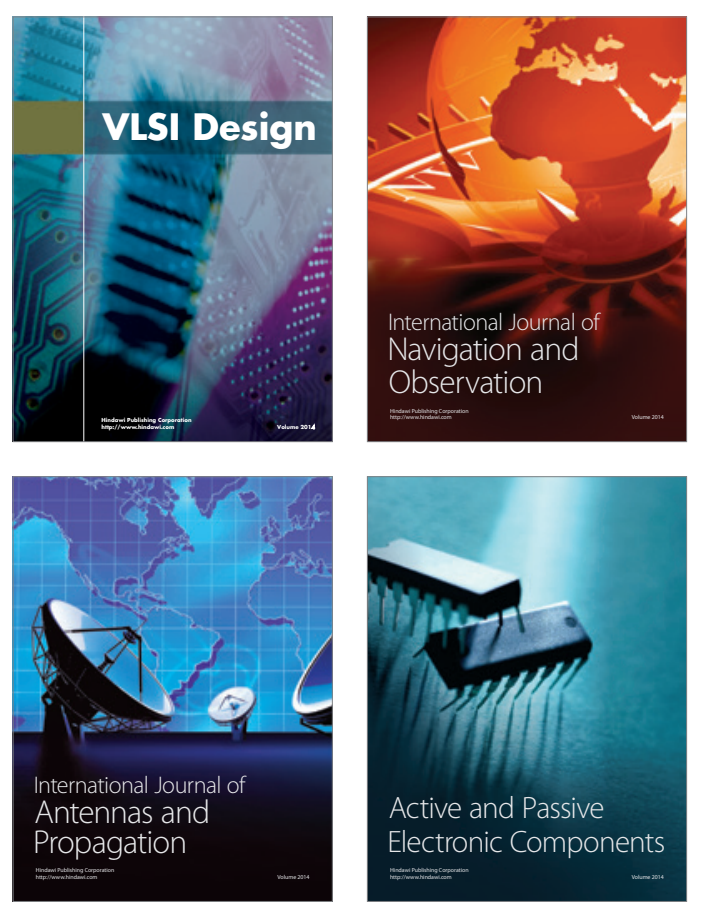
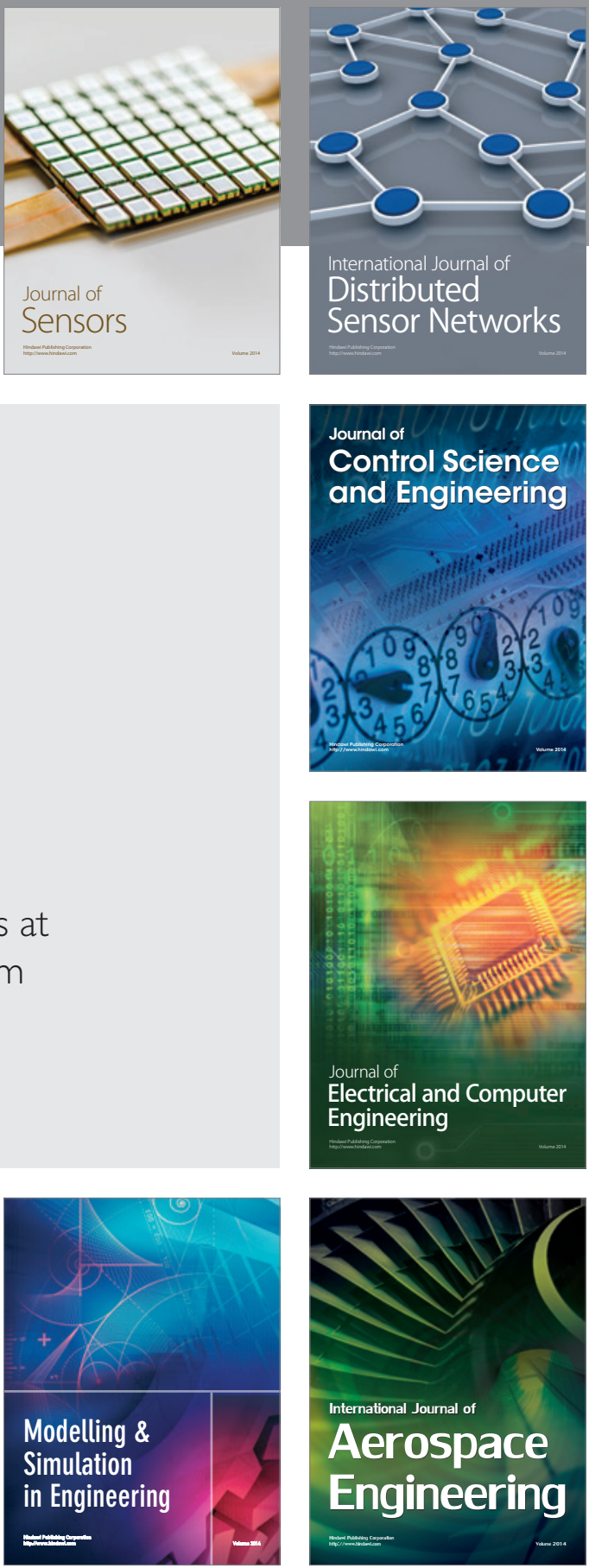

Journal of

Control Science

and Engineering
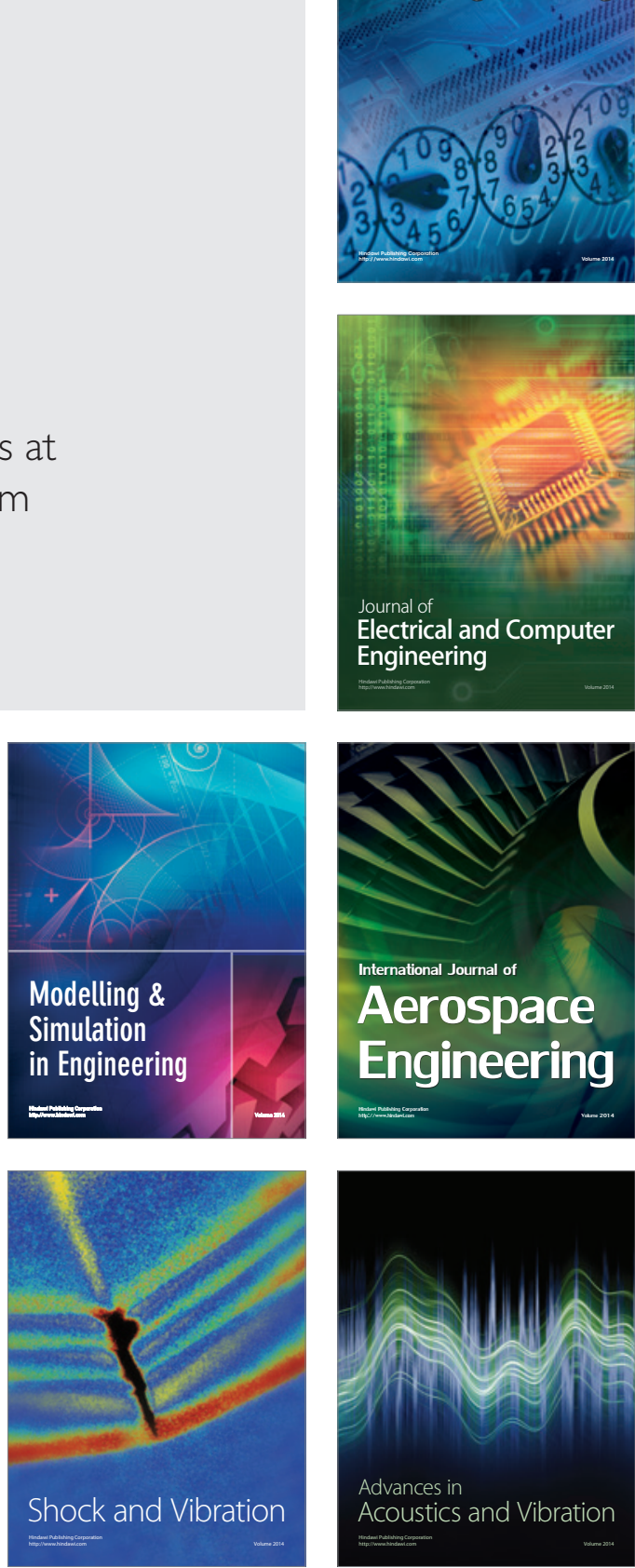